https://doi.org/10.46344/JBINO.2021.v10i02.16

\title{
DIETARY COPPER-FRUCTOSE INTERACTIONS ALTER THE URIC ACID LEVELS IN IN MALE RATS
}

\author{
Shimaa Mohammed Hasnin Aboelnaga .,Dr Salma Ahmed Ali Babiker .,Dr Fahmida Khatoon \& Dr Nuzhat \\ Perveen
}

\begin{abstract}
1 Associate professor, Deanship of Preparatory Year, University of Ha'il , Kingdom of Saudi Arabia
2Family Physician, Family Medicine, Hail University Clinics, University of Ha'il Kingdom of Saudi Arabia

3 Associate Professor, Department of Biochemistry, College of medicine, University of Ha'il

${ }^{4}$ Assistant Professor, Department of Obstetrics and Gynecology , College of medicine, University of Ha'il3
\end{abstract}

(Received on Date: 15 February 2021

Date of Acceptance: 1 March2021

Date of Publish: 19 March 2021)

E-mail : drfahmida24@gmail.com

\begin{abstract}
Dietary copper-fructose interactions contribute to the development of nonalcoholic fatty liver disease (NAFLD). Free radicals are any chemical species which possess one or several mismatched electrons They are capable of triggering chain reactions which can damage the different cell constituents. Oxygen, most vital for the human survival has on the same time deleterious potential. This is attributed to the formation, in vivo, of free radicals .Living organisms in the course of evolution has invented diverse and ingenious defense system to survive the toxicity of Oxygen. Urate radicals do not react with oxygen to form another peroxy radical, thus increasing the efficacy of various metal like zinc and copper as an antioxidant. Therefore, this study is designed to measure the level of coper and find out the association of coper in induced hyperuricemic rat model.Methodology: Study subject are forty male albino rats with an average weight of $180 \pm 2 \mathrm{~g}$ were selected. The rats were fed on standard diet and given tap water ad libitum until treatment. They were divided into four groups. Group A were control, group B rat fed on $60 \%$ fructose with standard diet, group C were fed on fructose, standard diet and intraperitonially oxonic acid $250 \mathrm{mg} / \mathrm{kg}$ and group D only on injection intraperotonially oxonic acid $250 \mathrm{mg} / \mathrm{kg}$. From rat heart $10 \mathrm{~mL}$ of blood was drawn and coper level were measured Results:Mean plasma level of copper of Control was found to be $19.59 \mathrm{mg} / \mathrm{dl}[ \pm 1.74]$. Group "F"[fructose] showed mean plasma copper of $12.38 \mathrm{mg} / \mathrm{dll}[ \pm 1.39]$.This reflects that copper fell down to $58 \%$ in rats which were exposed to diet comprising $60 \%$ Fructose than control. On comparing both groups i.e Control with Group "F"significant statistical correlation[P <0.01] was observed, Conclusion: Fructose diet produce hyperuricemia in rat. Copper level were statistically significant and correlated between control and other group.
\end{abstract}

Keywords: Uric Acid; Copper; Albino Rats; Fructose Induced Hyperuricemia 2021 March Edition | www.jbino.com | Innovative Association 


\section{Introduction}

Copper is an essential trace element required for different biological functions. investigate the effects induced by the over-exposure to copper in fructose induced hyperuricemic rat. The Free radicals formation takes place during several important redox reactions therefore there are several studies which have pointed out their biological significance Examples are of nitric oxide and Superoxide \&related ROS. Free radical can be defined as any molecular species capable of independent existence that contains an unpaired electron in an atomic orbital [1]. Nitric oxide is involved in smooth muscle relaxation [control of vascular tone] platelet inhibitorand various other cGMP-dependent functions. [2] While superoxide $\left[\mathrm{O}_{2}\right]$ and related ROS are involved in erythropoietin production ,smooth muscle relaxation,signal transduction from various membrane receptors/enhancement of immunological functions \&the maintenance of redox homeostasis.Superoxide through its derivative hydroxyl radical and hydrogen peroxide can induce second messenger cGMP ,T-cell growth factor interleukin 2, heme oxygenase [3]. Thus the delicate balance between the advantageous and detrimental effects of free radicals is clearly an important aspect of life. They are part of normal cellular metabolism so exist in certain measurable concentrations in cells[4]. Their concentrations are determined by the balance between their rates of production and clearance by various antioxidant compounds and enzymes. Inorder to check free radicals formation to avoid oxidative stress, body has different anti- oxidant defence systems..

Transition metal binding proteins: Ferritin, transferring, lactoferrin etc.also acts protective.Uric acid now is not considered as merely a metabolic waste. It has been proposed that increase in life span observed in human evolution to some extent might be due to protective action of uric acid[5].Uric acid along with albumin and ascorbic acid account for more than $85 \%$ of total antioxidant activity[6].Total radical trapping activity [TRAP] includes uric acid as major contributor as it accounts for $38-47 \%$ in comparison to vitamin $C$ and vitamin $E$ which account for 13-17\% and 2-8\% respectively [7] It has been found at contribute as much as two-thirds of all free radical scavenging activity in plasma therefore it serve as the most abundant aqueous antioxidant in humans It does so by preventing lipid peroxidation and quenching hydroxyl,superoxide and peroxynitrite radicals[8]. Increase uric acid levels have been found in oxidative stress and ischemia which might be compensatory mechanism of protection against free radicals [9].Urate radicals [UH2-]do not react with oxygen to form another peroxy radical which is seen with the ascorbic acid, thus increasing the efficacy of uric acid as an antioxidant [13].Uric acid cause inactivation of Nitric oxide and peroxynitrite radicals [10].Along with dopamine, uric acid also help in repair of oxidative free radical induced damage of DNA in certain brain cells[16].Another important function of urate is found in its ability to form chelating agents with 
transition metals ions like iron and copper ,thus scavenging them. This protects ascorbic acid from oxidation by these metals and interesting feature is that uric acid is itself does not get oxidized.[11].

In present study we have tried to elaborate whether hyperuricemia is the precursor or resultant feature of metabolic syndrome. We have also seen uric acid relationship with other antioxidants so that uric acid role as antioxidant may be established. Fructose an important commercially used sweetener, has been used as one of the mechanisms of inducing hyperuricemia in this study so that world should know d hazards of this sweetener

Copper is an essential trace element in all living organisms and serves as a cofactor of key metabolic enzymes that regulate physiological processes, including cellular respiration, antioxidant defense, and iron metabolism in eukaryocytes [12].Copper plays numerous important roles in body including wound healing, angiogenesis, etc. Copper chelation prevents tumour growth and non-intemal thickening after vascular injury [13].Copper [CU] is an essential trace element for humans and animals. In the body, copper shifts between the cuprous [ $\left.\mathrm{Cu}^{1+}\right]$ and cupric $\left[\mathrm{Cu}^{2+}\right]$ forms, though the majority of the body's copper is in the $\mathrm{Cu}^{2+}$ form. The ability of copper to easily accept and donate electrons explains its important role in oxidation-reduction [redox] reactions and in scavenging free radicals. Its antioxidant activity is exhibited by its presence in two enzymes superoxide dismutase and ceruloplasmin [14].In superoxide responsible of neutralizing superoxide radicals while in ceruloplasmin its antioxidant function is different.Ceruloplasmin is responsible for facilitating iron loading in transferrin so indirectly prevents free ferrous ions from participating in harmful free radical generating radicals [15].

\section{MATERIALS And Methods}

\section{Collection and storage of ANIMALS:}

Locally bred forty[40] male Albino rats as shown in figure 22-23 with an average weight of $180 \pm 20 \mathrm{~g}$ were purchased. The rats were grouped and housed in environmentally controlled room[ambient temperature $24 \pm 2^{\circ} \mathrm{C}$ and relative humidity of $55 \pm 5 \%$ ] in the animal house and acclimatized for 07 days. The animals were fed standard diet and given tap water ad libitum until treatment. The protocols for experimentation was approved and performed in strict accordance with the Guide for the care and use of laboratory animals [Institute of Laboratory Animal Resources on Life Sciences, US National Research Council, 1996] and the Institutional Animal Ethical Committee [IAEC] of Baqai Medical University, Karachi. Pakistan All animals housed in standard conditions were initially fed standard diet and allowed adaptation of one week. Albino rats were divided in four groups; $A, B, C$ \& D.

\section{Group A:}

Ten male albino rats as Control were kept as control and were fed standard diet and water ad libitum for 10 weeks.

\section{Group B:}

Ten male albino rats [ F]were fed $60 \%$ fructose mixed in standard diet and water ad libitum for 10 weeks. 


\section{Group C:}

Ten male albino rats [ FO]were fed $60 \%$ fructose mixed in standard diet and water ad libitum for 10 weeks. They were also injected intraperitonealy oxonic acid $250 \mathrm{mg} / \mathrm{kg}$ every third day for 10 weeks.

\section{Group D:}

Ten [10] male albino rats [O]were injected intraperitonealy oxonic acid $250 \mathrm{mg} / \mathrm{kg}$ every third day for 10 weeks. They were fed standard diet and water ad libitum for 10 weeks.

The amount of diet was measured before giving and then subtracted from the amount of food left over daily.

Collection of Blood :Approximately $10 \mathrm{mls}$ of blood was drawn from heart using disposable syringe $.8 \mathrm{mls}$ of blood was transferred in heparanized tube, mixed and centrifuged to separate plasma and divided in two epindorf cups for estimation of uric acid and sugar. $2 \mathrm{mls}$ of blood was transferred to glass tube and an equal amount of concentrated $\mathrm{HNO}_{3}$ was added to heat slowly and intermittently on sand bath avoiding boiling for next couple of days to obtain about $3 \mathrm{mls}$ of clear solution. This solution was diluted with deionized water, filtered and the volume was made up to $10 \mathrm{mls}$ with deionized water.Estimation Of Serum Uric Acid was done by Pap method [23].

\section{MEASUREMENT OF TRACE ELEMENTS:}

Trace element analysis was carried out on a Hitaci Z-8000 atomic absorption spectrometer equipped with Zeeman background correction and a data processor.flame atomization was used for Copper, Zinc and Magnesium estimation.

\section{Statistical analysis:}

Using SPSS 20 WAS carried out.

\section{Results:}

\section{COMPARISON OF PLASMA URIC ACID} LEVELS OF GROUP "F" WITH OTHER GROUPS:

Table 1 exhibits the correlation between mean plasma uric acid of Group "F" [with rest of the groups.The Group "F"[shows highly significant association $[P<0.001]$ with Control as described in section 1.1.1. The mean plasma uric acid level in Group "O" $3.63 \mathrm{mg} / \mathrm{dll}[0.22]$ which is only $13 \%$ more than Group " $F$ " [, therefore the $P$ value calculated were non- significant $[P>0.01]$. Group " $\mathrm{F}+\mathrm{O}$ " mean plasma uric acid i.e $4.43 \mathrm{mg} / \mathrm{dl}$ were comparatively higher than Group"F", therefore the highly significant correlation was observed $[P<0.001]$ between these two groups. This revealed that Fructose induced hyperuricemia augmented by uricase inhibitore raised urate level to $28 \%$ more than Group "F". 
Table 1:Comparison Of Uric Acid Levels [Mg\%] Of Group "F" With Other Groups

\begin{tabular}{|c|c|c|}
\hline GROUPS & $\begin{array}{l}\text { MEAN VALUES \& } \\
\text { SEM[Standard Error of Mean] }\end{array}$ & P-Values \\
\hline $\begin{array}{l}\text { GROUP } \\
\text { FRUCTOSE[F] }\end{array}$ & $\begin{array}{l}3.15 \\
\text { SEM } \pm 0.17\end{array}$ & \\
\hline $\begin{array}{l}\text { GROUP } \\
\text { CONTROL[C] }\end{array}$ & $\begin{array}{r}1.97 \\
S E M \pm 0.09\end{array}$ & $\begin{array}{l}\text { Gr "F" Vs Gr "C" } \\
P<0.001\end{array}$ \\
\hline $\begin{array}{l}\text { GROUP } \\
\text { OXONIC ACID[O] }\end{array}$ & $\begin{array}{r}3.63 \\
\text { SEM } \pm 0.22\end{array}$ & $\begin{array}{l}\text { Gr "F" Vs Gr "O" } \\
P>0.01\end{array}$ \\
\hline $\begin{array}{l}\text { GROUP } \\
\text { FRUCTOSE+OXONIC } \\
\text { ACID[F+O] }\end{array}$ & $\begin{array}{r}4.41 \\
\text { SEM } \pm 0.14\end{array}$ & $\begin{array}{l}\text { Gr "F" Vs Gr "F+O" } \\
P<0.001\end{array}$ \\
\hline
\end{tabular}

COMPARISON OF PLASMA COPPER LEVELS OF CONTROL WITH OTHER GROUPS:

Table 2 shows the comparison of mean plasma copper levels of Control with rest of the groups. Mean plasma level of copper of Control was found to be 19.59 $\mathrm{mg} / \mathrm{dl}[ \pm 1.74]$.Group "F"[fructose] showed mean plasma copper of 12.38 $\mathrm{mg} / \mathrm{dl}[ \pm 1.39]$.This reflects that copper fell down to $58 \%$ in rats which were exposed to diet comprising $60 \%$ Fructose than control. On comparing both groups i.e Control with Group "F"significant statistical correlation[P $<0.01]$ was observed.The mean plasma copper levels of Group "O" [oxonic acid] was $20.6 \mathrm{mg} / \mathrm{dl}[ \pm 1.40$ ] which is only $5 \%$ higher than Control. The probability calculated was non-significant [P>0.01] when both groups were evaluated.

While comparing Group " $\mathrm{F}+\mathrm{O}$ "[Fructose +Oxonic acid] with Control, significant correlation was observed $[\mathrm{P}<0.01]$.It was due to $63 \%$ decrease in plasma serum copper levels bringing levels to $11.95 \mathrm{mg} / \mathrm{dl}[ \pm 1.45]$ in Group $\mathrm{F}+0 . \mathbf{2 3 . 7 . 2}$. COMPARISON OF PLASMA COPPER LEVELS OF GROUP F WITH OTHER GROUPS:

Table 3.7.2 exhibits the correlation between mean plasma copper of Group "F"[with rest of the groups. The Group "F"shows significant association $[\mathrm{P}<0.01]$ with Control as described in section 3.7.1. The mean plasma copper levels in Group O were $20.6 \mathrm{mg} / \mathrm{dl}[ \pm 1.40]$ which is $40 \%$ more 
than Group "F", therefore the P value calculated were highly significant $[P<0.001]$.

Group $\mathrm{F}+\mathrm{O}$ mean plasma copper was found to be $11.95 \mathrm{mg} / \mathrm{dl}$ which is only 03\%more than Group"F", therefore the non-significant correlation was observed $[P>0.01]$ between these two groups.

TABLE 2:COMPARISON OF COPPER LEVELS [mg\%] OF GROUP "C" WITH OTHER GROUPS

\begin{tabular}{|c|c|c|}
\hline GROUPS & $\begin{array}{l}\text { MEAN VALUES \& } \\
\text { SEM[Standard Error of } \\
\text { Mean] }\end{array}$ & P-Values \\
\hline GROUP CONTROL[C] & $\begin{array}{r}19.59 \\
\text { SEM } 1.74\end{array}$ & \\
\hline GROUP FRUCTOSE[F] & & $\mathrm{Gr} " \mathrm{C}$ \\
\hline GROUP OXONIC ACID[O] & $\begin{array}{r}20.6 \\
\text { SEM } \pm 1.40\end{array}$ & $\begin{array}{l}\text { Gr "C" Vs Gr "O" } \\
P>0.01\end{array}$ \\
\hline $\begin{array}{l}\text { GROUP } \\
\text { FRUCTOSE+OXONIC } \\
\text { ACID[F+O] }\end{array}$ & $\begin{array}{r}11.95 \\
\text { SEM } 1.45\end{array}$ & $\begin{array}{l}\text { Gr "F" Vs Gr "F+O" } \\
P<0.01\end{array}$ \\
\hline
\end{tabular}




\begin{tabular}{|c|c|c|}
\hline GROUPS & $\begin{array}{l}\text { MEAN VALUES \& } \\
\text { SEM[Standard Error of } \\
\text { Mean] }\end{array}$ & P-Values \\
\hline $\begin{array}{l}\text { GROUP } \\
\text { FRUCTOSE[F] }\end{array}$ & $\begin{array}{r}12.38 \\
\text { SEM } \pm 1.39\end{array}$ & \\
\hline $\begin{array}{l}\text { GROUP } \\
\text { CONTROL[C] }\end{array}$ & $\begin{array}{r}19.59 \\
\text { SEM } 1.74\end{array}$ & $\begin{array}{l}\text { Gr "F" Vs Gr "C" } \\
P<0.01\end{array}$ \\
\hline GROUP OXONIC ACID[O] & 20.6 & Gr"F" Vs Gr "O" \\
\hline $\begin{array}{l}\text { GROUP } \\
\text { FRUCTOSE+OXONIC } \\
\text { ACID[F+O] }\end{array}$ & $\begin{array}{r}11.95 \\
\text { SEM } \pm 1.45\end{array}$ & $\begin{array}{l}\text { Gr "F" Vs Gr "F+C } \\
P>0.01\end{array}$ \\
\hline
\end{tabular}

COMPARISON OF PLASMA COPPER LEVELS OF GROUP "O" WITH OTHER GROUPS:

Table 4 shows the statistic connection of Group "O"[Oxonic Acid] with the rest of the groups. The comparison of Group "O" with control was non- significant $[P>0.01]$ and with Group $F$ was highly significant $[\mathrm{P}<0.001]$ as describe before.
The Group "O"showed highly significant correlation $[\mathrm{P}<0.001]$ with Group $\mathrm{F}+\mathrm{O}$ as the mean serum copper levels of Group "F+O"are $72 \%$ lower than Group "O" reflecting that copper levels decreased significantly in rats which were treated with oxonic acid along with dietary fructose in comparison to rats which were injected with Oxonic acid alone. 
COMPARISON OF PLASMA COPPER LEVELS OF GROUP F+O WITH OTHER GROUPS:

Table 5 reflects the statistical comparison of Group $\mathrm{F}+\mathrm{O}$ with the rest of the groups. Mean plasma copper of this group [ $\mathrm{F}+\mathrm{O}]$ were found to be highest of all groups. The statistic correlation were found to be significant $[\mathrm{P}<0.01]$ when Group $\mathrm{F}+\mathrm{O}$ was evaluated with

Control ,nonsignificant[P>0.01] with Group F while highly-significant when compared to Group O. $[\mathrm{P}<0.001]$

\section{TABLE 4:COMPARISON OF COPPER LEVELS OF GROUP "O" WITH OTHER GROUPS}

\begin{tabular}{|c|c|c|}
\hline GROUPS & $\begin{array}{l}\text { MEAN VALUES \& } \\
\text { SEM[Standard Error of } \\
\text { Mean] }\end{array}$ & P-Values \\
\hline $\begin{array}{l}\text { GROUP } \\
\text { OXONIC ACID[O] }\end{array}$ & $\begin{array}{r}20.6 \\
\text { SEM } \pm 1.40\end{array}$ & \\
\hline $\begin{array}{l}\text { GROUP } \\
\text { CONTROL[C] }\end{array}$ & $\begin{array}{r}19.59 \\
\text { SEM } \pm 1.74\end{array}$ & $\begin{array}{l}\text { Gr "O" Vs Gr "C" } \\
P>0.01\end{array}$ \\
\hline $\begin{array}{l}\text { GROUP } \\
\text { FRUCTOSE[F] }\end{array}$ & $\begin{array}{r}12.38 \\
\text { SEM } \pm 1.39\end{array}$ & $\begin{array}{l}\text { Gr "O" Vs Gr "F" } \\
P<0.001\end{array}$ \\
\hline $\begin{array}{l}\text { GROUP } \\
\text { FRUCTOSE+OXONIC } \\
\text { ACID[F+O] }\end{array}$ & $\begin{array}{r}11.95 \\
\text { SEM } \pm 1.45\end{array}$ & $\begin{array}{l}\text { Gr "O" Vs Gr "F+O" } \\
P<0.001\end{array}$ \\
\hline
\end{tabular}


TABLE 5.:COMPARISON OF COPPER LEVELS OF GROUP "F+O" WITH OTHER GROUPS

\begin{tabular}{|c|c|c|}
\hline GROUPS & $\begin{array}{l}\text { MEAN VALUES \& } \\
\text { SEM[Standard Error of } \\
\text { Mean] }\end{array}$ & P-Values \\
\hline $\begin{array}{l}\text { GROUP } \\
\text { FRUCTOSE+OXONIC } \\
\text { ACID[F+O] }\end{array}$ & $\begin{array}{l}11.95 \\
\text { SEM } \pm 1.45\end{array}$ & \\
\hline $\begin{array}{l}\text { GROUP } \\
\text { CONTROL[C] }\end{array}$ & $\begin{array}{r}19.59 \\
\text { SEM } \pm 1.74\end{array}$ & $\begin{array}{l}\text { Gr "F+0" Vs Gr "C" } \\
P<0.01\end{array}$ \\
\hline $\begin{array}{l}\text { GROUP } \\
\text { FRUCTOSE[F] }\end{array}$ & & $\begin{array}{l}G r " F+O " V s \\
P>0.01\end{array}$ \\
\hline $\begin{array}{l}\text { GROUP } \\
\text { OXONIC ACID[O] }\end{array}$ & $\begin{array}{r}20.6 \\
S E M \pm 1.40\end{array}$ & $\begin{array}{l}\text { Gr "F+O" Vs Gr "O" } \\
P<0.001\end{array}$ \\
\hline
\end{tabular}

Discussion:

In present study uric acid was found to be increased in all three groups, $G=$ Fructose, $G=$ Oxonic acid and $G=F r u c t o s e+O x o n i c$ acid when the levels were compared with the Control[C],but considerable variations in levels were observed in these groups as shown in Tab3 in the section of results. The mean serum level of uric acid in $\mathrm{G}=$ Fructose+Oxonic was highest of all three study groups being 
$55 \%$ more than control,28\% more than Fructose treated only and $18 \%$ higher than Oxonic acid treated hyperuricemic rats. These findings are in consistent with several other studies which have shown that fructose can increase uric acid levels $[16,17]$. The proposed mechanism by which fructose might have increased uric acid production is that fructose is rapidly phosphorylated by fructokinase to fructose-1-phosphate on entering the hepatocytes by passing the regulatory step of glycolysis. [18].ADP is generate due to donation of Phosphate by ATP during this reaction.This ADP is then furthur metabolized to uric acid[19]. Fructose may also increase latcate production which is a competitive inhibitor for urate excretion [20]. In addition to this Fructose might also have role in hyperinsulinemia which may also have contributed to impairment in urate excretion by promoting renal reabsorption [21]. Finaly resultant hyperuricemia due to fructose itself impaired its own excretion as demonstrated in several studies by causing endothelial dysfunction and renal vasoconstriction[22]. The different magnitude of hyperuricemia observed might be due to the reason that in rats hepatic enzyme uricase [urate oxidase] is present which is responsible for converting uric acid to allontoin.Due to this reason the normal levels are kept in range of 0.5 to $1.5 \mathrm{mg} / \mathrm{dl}[22]$. This was well demonstrated in present study in the $\mathrm{G}=$ Oxonic acid and $G=$ Fructose + Oxonic acid in which uric acid considerably increased when uricase inhibitor "Oxonic acid" was added.
During minerals estimation in the present study, the levels of Copper were found to be decreased in all groups when compared with the control and lowest levels of $11 \mathrm{mg} / \mathrm{dl}$ observed in the $\mathrm{G}=\mathrm{F}+\mathrm{O}$

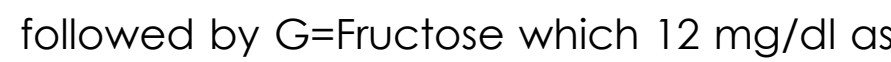
shown in Taband Graph 3.7.It is interested to be noted here in both groups the common factor is fructose. These findings are in agreement with Boyd L O'Dell in 1993[39] who pointed out that fructose decreases copper bioavailability when it forms $60 \%$ of the diet.This is augmented by Koh et al[23] who demonstrated in their experimental study that in copper level was found to be higher in those group of rats in which copper was injected in comparison to rats in which copper was given orally. These reflects that fructose might be interfering with the copper absorption at intestinal level as both groups were supplemented with dietary fructose. The possible explaination as proposed by M.Fields et al[24] research in which it was proposed that high concentration of fructose in diet might reduce copper resulting its precipitation as cuprous oxide. This form is highly insoluble so its transport across the intestinal cells can be hampered.

\section{Conclusion}

Copper level between the groups are significantly correlated Antioxidants such as copper and zinc and some vitamins like $C, E$ and $A$ are important to include in diet. It is recommended to include copper containing vegetables and fruit daily to reduce their deficiency. 


\section{References；}

1 Mladenović, M.J., Paunović, M.G., Matićl, M.M., Knežev, V.S., Ognjanović, B.I.,

Štajn, A.Š. and Saičić, Z.S. (2014): Copperinduced changes of lipid

peroxidation and hemato-biochemical parameters in rat blood: protective role

of flavonoids. Arch. Biol. Sci., Belgrade, 66 (3):1271-1279.

2 Radomski MW, Palmer RM, Moncada S. The anti-aggregating properties of vascular endothelium: interactions between prostacyclin and nitric oxide. $\mathrm{Br} J$ Pharmacol. 92[3]:639-46, 1987.

3 Keyse SM And Tyrrel RM. Heme oxygenase is the major 32-kDa stress protein induced in human skin fibroblasts by UVA radiation, hydrogen peroxide, and sodium arsenite. Proc Natl Acad Sci USA86: 99-103, 1989.

4 Sies H. Strategies of antioxidant defense. Eur J Biochem 215: 213-219, 1993.

5 Wulf Droge. Free Radicals in the Physiological Control of Cell Function Physiol Rev. VOL 82 .JANUARY, 47-95, 2002.

6 Kelvin J. A. Davies, Alex Sevanian, Samar F. Muakkassah-Kelly and Paul Hochstin.Uric acid-iron ion complexes $A$ new aspect of the antioxidant functions of uric acid. Biochem. J. 235, 747-754, 1986

7 Peña MM, Lee J, Thiele DJ. A delicate balance: homeostatic control of copper uptake and distribution. J Nutr. 129[7]:125160, 1999.

8 Hoon Shim and Z. Leah Harris. Genetic Defects in Copper Metabolism . J. Nutr. vol. 133 no. 5 1527S-1531S, 2003

9 Shinichi Itoh, Ha Won Kim, Osamu Nakagawa, Kiyoshi Ozumi, Susan M. Lessner, Hiroki Aoki, Kamran Akram, Ronald D. McKinney, Masuko Ushio-Fukai, and Tohru Fukai. Novel Role of Antioxidant-1 [Atox 1] as a Copper-dependent Transcription Factor Involved in Cell Proliferation. J Biol Chem. 283[14]: 91579167, 2008

10 Uauy R, Olivares M, Gonzalez M. Essentiality of copper in humans. Am J Clin Nutr. 67[5 Suppl]:952S-959S, 1998.

11 Linder MC, Hazegh-Azam M. Copper biochemistry and molecular biology. Am J Clin Nutr. Vol, 63 no, 5 797S-81 1S, 1996.

12 .Sun SZ, Empie MW:Lack of findings for the association between obesity risk and usual sugar-sweetened beverage consumption in adults a primary analysis of databases of CSFII-198-1991, CSFII-1994-1998 NHANES III, and combined NHANES 1999-2002 Food Chem Toxicol 2007, 45:1523-1536.

13 Sun SZ, Flickinger BD, Williamson-Hughes PS, Empie MW:Lack of association between dietary fructose and hyperuricemia risk in adults. Nutr Metab [Lond] 2010, 7:16.

14 Sirirat Reungjui, Marcelo Heinig, Michael Gersch, Yuri Sautin, Takahiko Nakagawa and Richard J. Johnson. Uric Acid, the Metabolic Syndrome, and Renal Disease. J Am Soc Nephrol 17: 165-168, 2006 
15 Pietro Cirillo, Waichi Sato, Marcelo Heinig, Michael Gersch, Yuri Sautin, Takahiko Nakagawa and Richard J. Johnson. Uric Acid, the Metabolic Syndrome, and Renal Disease . J Am Soc Nephrol 17: 165-168, 2006

\section{Lingegowda, Puneet} Sood,Takahiko Nakagawa,Quoc C. Van,Bhagwan Dass and Abutaleb Ahsan Ejaz. A novel role for uric acid in acute kidney injury associated with tumour lysis syndrome. Nephrol. Dial. Transplant. [10]: 2960-2964, 2009

17 Hallfrisch J. Metabolic effects of dietary fructose. The FASEB Journal, Vol 4, 26522660, 1990

18 Chin-Hsiao Tseng. Correlation of uric acid and urinary albumin excretion rate in patients with type 2 diabetes mellitus in Taiwan. Kidney International. 68, 796-801, 2005

19 Rao Ivaturi and Constance Kies.Mineral balances in humans as affected by fructose, high fructose corn syrup and sucrose, Plant Foods for Human Nutrition [Formerly Qualitas Plantarum].Volume 42, Number 2, 143-151,1992

20 Facchini F, Chen YD, Hollenbeck CB, and Reaven GM. Relationship between resistance to insulin-mediated glucose uptake, urinary uric acid clearance, and plasma uric acid concentration. JAMA 266: 3008-3011, 1991

21 Khosla UM, Zharikov S, Finch JL, Nakagawa T, Roncal C, MU W, Krotova K, Block ER, Prabhakar $S$, and Johnson RJ. 2021 March Edition | www.jbino.com | Innovative Association
Hyperuricemia induces endothelial dysfunction. Kidney Int 67: 1739-1742, 2005.

22 O'Dell BL. Fructose and mineral metabolism. Am J Clin Nutr. 58[5 Suppl]:771S-778S, 1993.

23 Koh ET, Ard NF, Mendoza F:Effects of fructose feeding on blood parameters and blood pressure in impaired glucosetolerant subjects.J Am Diet Assoc 1988,8[8] b:932-938.

24 Meria Fields, Janet Holbrook, T Daniel Scholfield, AZ. J. Cecil Smith, JR, Azand Sheldon Reiser Azandolos Almanos. Effect of Fructose or Starch on Copper-67 Absorption and Excretion by the Rat. J Nutr. 116;625-32, 1986. 